\title{
The Effectiveness of ECOLA Technique to Improve Reading Comprehension in Relation to Motivation and Self-Efficacy
}

\author{
https://doi.org/10.3991/ijet.v15i01.11495 \\ Haerazi $(\bowtie)$, Lalu Ari Irawan \\ English Language Education, Mandalika University of Education, Indonesia \\ haerazi@ikipmataram.ac.id
}

\begin{abstract}
This study was aimed at finding out whether; (1) the use of the Extending Concept through Language Activities (ECOLA) technique is more effective than brainstorming technique in teaching reading comprehension; (2) there is any difference of reading comprehension achievement of students taught by using ECOLA technique; and (3) there is an interaction between ECOLA technique, motivation, and self-efficacy towards students' reading comprehension. This study is a quasi-experimental research with a nonequivalent group design. Two classes were taken as the sample by using cluster random sampling. One class, as an experimental class, was taught by using the ECOLA technique. Another class, as a control class, was taught by employing the brainstorming technique. To attain the data, instruments in the form of a reading test and the questionnaires were employed. Afterwards, the data were analyzed by using Multifactor Analysis of Variance (Two Way ANOVA). The finding of this study showed that; (1) the ECOLA technique was more effective than the brainstorming technique in teaching reading comprehension; (2) there was the difference of reading achievement of students taught using the ECOLA technique viewed from the motivation and self-efficacy and it was indicated by the value of sig. (0.001) and (0.004); and (3) there was the interaction between ECOLA technique and self-efficacy towards students' reading comprehension but there was no interaction between the technique and motivation. In addition, there was no significant interaction between the technique, motivation, and selfefficacy because it was indicated by the value of sig (0.302) was higher than significant level 0.05 . To improve students' reading comprehension, the ECOLA technique is recommended and the attention of moderate variables is encouraged.
\end{abstract}

Keywords - ECOLA technique, motivation, self-efficacy, and reading comprehension

\section{Introduction}

Reading is often a promising skill to be acquired by students because reading is considered as one of the language skills that should be mastered by students. Reading 
needs an awareness of comprehension during reading activities. According to [1], "reading is primarily reflected as a dynamic meaning-focused interaction in which students are required to build comprehension of a text in a non-linear way". Therefore, reading activities provide opportunities for students to learn language and then to construct sentences, paragraphs, and texts.

Because reading gives students many advantages, many teachers or lecturers utilize technology devices for their teaching and learning. Mobile devices and social media tools are used to improve students' reading skills, vocabulary acquisition, critical thinking and learning support [2], [3], [4], [5] \& [6]. In addition, many instructional methods and models are applied to help students develop their reading skills. Kamalian et al. [7] apply the task-based learning model to improve students' reading activities; the computerized graphic organizer (CGO) learning to enhance reading performance [8]; web platform for reading examination system, [9], Computer multimedia [10] and Timed Reading and genre-based reading to increase reading comprehension [11]. These efforts are oriented to promote students' reading skills.

Despite the promising functions of EFL reading, Djiwandono [12]; [13]; and [14] inform that the existing strategies or methods of teaching reading in Indonesia fail to promote students' autonomous skills to cope with English texts. Indonesian students as EFL readers face more difficult tasks than native readers in reading texts which are written in English [13] \& [15].

In reading, some problems are faced by students to get comprehension in reading. Students have a lack of new vocabularies when they read new discourse such as economic, political, and law texts. In addition, they have problems in grammar knowledge when they meet the complex structure texts. In this situation, they rely heavily on their lecturers and do not have a chance to be involved in active learning. In response to this, lecturers should attend an appropriate instructional strategy to handle those problems. Sugirin [13] states reading problems in English are both problems in line with language proficiency and those related to reading skills and strategies. The reading problems with language proficiency is then called language problems, whereas the problems relating to reading skills is called reading problems.

Students as EFL learners faced not only dealing with reading skills and proficiencies but the internal factors such as reading motivation and self-efficacy. These external factors can influence students' reading abilities in the class. Most Asian students as EFL learners have difficulties due to students' external factor in reading texts written in English [16]; [17]; [18]. At the level of private universities, students still feel unconfident, unworthy, and incompetent to complete their reading tasks. They also feel that they have problems with their language proficiency and reading skills to comprehend English books or texts. The level of motivation and self-efficacy affected them to attain the reading achievement in the class.

To cope with both language problems and reading problems, this study proposed a reading strategy or technique, namely ECOLA (Extending Concept through Language Activities). It is a reading technique focusing on students to involve in active learning through full language activities. The targeted goal of this technique is to enhance students' natural reading abilities. The language problems and reading skills are minimized through the stages of this technique. The stages of this include determining 
communicative goals for reading, written response or reading silently, discussion, and self-monitoring in writing and comparing activities.

This study was aimed at finding the effectiveness of ECOLA technique in teaching reading comprehension viewed from students' motivation and self-efficacy. In addition, it aims to know whether there is any difference of students' reading comprehension taught by using ECOLA technique viewed from motivation and selfefficacy. Furthermore, it aims to find out whether any interaction between ECOLA technique, motivation, and self-efficacy towards students' reading comprehension for the fourth-semester students of English language education program study.

\section{Literature Review}

\subsection{Reading skills}

Reading as one of the language skills is basically a negotiation process that exists between readers and writers. Matsuda [19], [20] and [21] explain that reading is a transaction process when the reader negotiates the meaning or interpretation of the text being read. The meaning of a text that is read does not come naturally to the reader. The reading process is complex. In the reading activities, there is a negotiation process that continues until the meaning appears. The process is influenced by the context of the situation and cultural context.

The negotiation process is in the form of a set of ideas or thoughts contained in the text. The reader processes the interaction between the mind, the eye, and the text that is read as a representation of the opposite of communication, namely the writer [22]. For readers who have knowledge, concepts, and experiences (which have become schemata), the interaction process in analyzing meaning will take place more effectively than those who do not have the schema. Readers need to have the background knowledge that is relevant to the topic of reading. However, in reality, the knowledge that is relevant to the topic of reading is not enough to improve reading skills [23]. Other skills are needed to connect the knowledge that is owned by the topic being read. Reading learning should help learners utilize their knowledge to support reading skills, namely analyzing meaning [24].

Reading can be seen as a process and as a result. Reading as a process consists of several stages carried out by the reader through a number of certain activities and techniques. One of the reading processes that occur in reading activities is decoding [25] and driven activities [26]. Meanwhile, reading as a result of communication achievements in the process of transactions or negotiations takes place between readers and writers [27]. These achievements can be in the form of ideas or thoughts which are then called reading comprehension.

Reading is not a passive process but active [27] and [28]. The reader actively tries to capture the contents of the reading. As a negotiation process, readers don't just take it for granted. Readers are also not identical to the memorizing activities. The most important thing in reading activities is to capture the message or main idea of reading better which is conveyed by the author through the text being read [22]. 


\subsection{Motivation}

Feng \& Chen [29] state "motivation as the combination of effort and desire to reach the learning goals and favorable attitude towards learning the language". It also refers to the directed effort of individual students to learn the language. Therefore, the effects of students' orientation are associated with motivation and motivation and achievement are directly interrelated. Ellis [30] claims "the strength of motivation serves as a power of predictor of ELT achievement".

Motivation determines how much students will be involved in learning activities. Those who have high motivation will be more eager to be involved in learning [31]. Meanwhile, students who have low motivation will tend to be passive. Of course, there will be two different responses that will have a different effect on increasing reading comprehension [32].

Language learning will be influenced by the level of learners' motivation. Motivation can arise from intrinsic and extrinsic students [21]. Intrinsic motivation is related to the encouragement that comes from the students themselves. The form of intrinsic motivation in the form of awareness of the benefits obtained from the learning process. Meanwhile, extrinsic motivation comes from outside students. The form can be in the form of encouragement from others or in the form of rewards, such as gifts, money, or value [21], [32], [33].

A number of studies show that intrinsic motivation is more meaningful than extrinsic motivation [34] and [35]. This first type is more natural than the second type. In the context of teaching reading, intrinsic motivation whose form can be in the form of awareness of the benefits obtained from the reading process [29]. It can be done by entering the stage of developing motivation before the reading phase is carried out. This step can be done through efforts to invite students to formulate their communicative goals in reading. The formulation of communicative goals is carried out because of the awareness that each person has a different goal when dealing with reading texts. The formulation of objectives is basically the formulation of beneficial aspects that can be obtained from the reading process.

\subsection{Self-efficacy}

Another aspect that needs to be considered is self-efficacy. Ordinary self-efficacy is defined as a psychological tendency to believe that he is able to complete an activity. Students who have good self-efficacy will tend to have good motivation too [36] and [37]. Conversely, learners who have low self-efficacy have the potential to be lackluster. Learners' confidence that they are not able to understand a reading text will affect motivation and subsequent involvement [37]. Efforts to overcome this problem are carried out by exploring the schemes that students have. This method will be better carried out before the reading process begins. Students can hold discussions related to the initial knowledge of the topic contained in the reading text [38] and [39]. This step can grow both learners' self-efficacy and reading comprehension.

Bandura [40] states self-efficacy is people's belief of which they have capabilities to perform specific tasks. It is also defined as students' belief about their own aca- 
demic capabilities. Pajares [41] depicts that self-efficacy can influence students' cognition, motivation, effective activity, and behavior. Therefore, in the teaching-learning process, self-efficacy has an important role to regulate students' behavior to reach the learning success. According to [37], the role of self-efficacy plays on the process of self-regulation in which it can affect students' choices psychologically to complete their reading and writing tasks.

In line with Bandura, Pintrich et al. [42] note that self-efficacy is self-appraisal of students' ability which becomes the foundation for self-confidence and motivation to perform and excel their learning tasks. According to Bandura [40], "self-efficacy is affected by four factors:

- Past experience of success and failure

- Vicarious experience or modeling, in which observing a partner's success and failure serves to increase or decrease one's self-efficacy

- Social persuasion (encouragement or discouragement) from others

- The persons' belief about their ability"

\subsection{ECOLA technique in teaching reading}

ECOLA (Extending Concept through Language Activities) developed by SmithBurke [43]. This technique seeks to integrate all language skills (reading, writing, speaking, and listening) for the purpose of developing reading skills only. The hope is that the learners' ability in developing their reading skills can be interpreted and supervised.

According to Smith-Burke (in Tierney, 1990: 154) [44], ECOLA is focused on learners who enhance their natural reading abilities and monitoring needs to ensure that their interpretations are appropriate. For this purpose, the most important framework of ECOLA learning lies in the following learning experiences.

- Read with a specific purpose. The purpose of reading the text was developed based on the author's intentions and several reasons why the teacher chose the reading. However, the purpose of reading is still determined by the readers themselves.

- Written response. Readers are expected to carry out their own interpretation as outlined in writing activities. The results of these interpretations can be reviewed after they have discussed.

- Discussion. Discussion is seen as a basis for generating the right ideas to test goals, evaluate meaning, and consider the efficacy of the strategies used by students when reading.

- Self-monitoring. Learners are encouraged to express their confusion, to interpret independently, and to discuss strategies for understanding the texts being reading well. 
ECOLA is built through five stages, namely:

- Determine communicative goals for reading

- Reading silently for a purpose and standard of duty

- Realizing an understanding through writing activities

- Carry out discussions and clarification on meaning

- Write and compare.

Explanation of each of these stages can be seen in Table 1.

Table 1. Stages of ECOLA technique

\begin{tabular}{|c|c|c|}
\hline Stages & Teachers' Activities & Students' Activities \\
\hline $\begin{array}{l}\text { Determine } \\
\text { communicative } \\
\text { goals }\end{array}$ & $\begin{array}{l}\text { Encourage students to hold a small discussion to } \\
\text { determine the purpose of the reading activities. } \\
\text { Give a brief explanation of the reading materials. }\end{array}$ & $\begin{array}{l}\text { In a small discussion, students } \\
\text { determine their own aims to } \\
\text { read. } \\
\text { Students enact their own aims to } \\
\text { read in the class. }\end{array}$ \\
\hline $\begin{array}{l}\text { Reading } \\
\text { silently }\end{array}$ & $\begin{array}{l}\text { Direct students to remind their aims of reading. } \\
\text { Help students interpret ideas from reading based } \\
\text { on their reasons. }\end{array}$ & $\begin{array}{l}\text { Students interpret their ideas } \\
\text { from reading based on their } \\
\text { background knowledge. }\end{array}$ \\
\hline $\begin{array}{l}\text { Realizing a } \\
\text { comprehension } \\
\text { through writ- } \\
\text { ing activities }\end{array}$ & $\begin{array}{l}\text { Help students carry out self-monitoring. } \\
\text { Encourage students to write things that they do } \\
\text { not understand. }\end{array}$ & $\begin{array}{l}\text { Students express what they do } \\
\text { not understand. } \\
\text { Students write responses to all } \\
\text { questions of the purpose of } \\
\text { reading. } \\
\text { Students ask other learners } \\
\text { about the problems they face. }\end{array}$ \\
\hline Discussion & $\begin{array}{l}\text { Organize students into groups, no more than four } \\
\text { people each group and given a certain time limit. } \\
\text { Organize discussion rules. }\end{array}$ & $\begin{array}{l}\text { Students discuss the results of } \\
\text { interpretation, compare respons- } \\
\text { es, and change their conclusion. } \\
\text { Each student exchange respons- } \\
\text { es and explain the basis of their } \\
\text { conclusion. }\end{array}$ \\
\hline $\begin{array}{l}\text { Write and } \\
\text { compare }\end{array}$ & $\begin{array}{l}\text { Encourage students to discuss interpretation that } \\
\text { has been completed. }\end{array}$ & $\begin{array}{l}\text { Students express their strategies } \\
\text { for understanding the reading. } \\
\text { Students write what they have } \\
\text { understood from the reading. } \\
\text { Students bring up another inter- } \\
\text { pretation in the class and com- } \\
\text { pare other interpretation com- } \\
\text { pletely. }\end{array}$ \\
\hline
\end{tabular}

ECOLA (Extending Concepts through Language Activities) technique can improve reading comprehension skills. This can happen because this technique contains a process of monitoring the results of the interpretation. In addition, the ECOLA technique can encourage learners to discuss effective strategies to gain a good understanding. The process of the discussion carried out in this technique is aimed at building and increasing learners' ability to collaborate in teams. Collaboration is a strategic step to improve and gain a better understanding of reading. 


\section{Research Method}

\section{1 $\quad$ Research setting}

This study was conducted at the fourth and sixth semester of English language department at IKIP Mataram in the academic year of 2018/2019. It is located in Mataram, West Nusa Tenggara Indonesia. The population of this study includes four classes that are IVA, IVB, VIA, VIB. The total number of it was 120 students. The IVA and VIB class were randomly selected as samples of the study by using a cluster random sampling. The students of IVA class were applied as an experimental class and those of VIB class were employed as a control class. The experimental and control class consisted of 29 students.

\subsection{Research design}

This study includes a quantitative study and it can be classified into quasiexperimental research. The research design uses a pretest and posttest with nonequivalent groups which involve a group of students who belong to the experimental class and another class as the control class. According to Kothari [45], the principle of an experimental study is that if two identical groups are taken, one of which is given special treatment and the other is not. In this study, the special treatment given is the application of ECOLA technique in teaching reading comprehension.

The researchers organized pretest in both classes to meet students' initial reading skills before the two classes are given treatments. Afterwards, the researcher gave the ECOLA technique to the IVA class as the experimental class and a conventional technique is provided to the VIB class as the control class. After organizing the pretest for the two classes, the researchers administered the posttest to both to see the students' reading achievement after the treatments were provided. In addition, the motivation and self-efficacy were as attributed variable and were assumed as the independent variable that influences the students' reading comprehension.

\subsection{Instruments and technique of collecting data}

The researchers made a reading test for students in the control and experimental class. The researchers distributed the reading test to students in the pretest before treatment and in the posttest after treatment. Meanwhile, to collect data on students' motivation and self-efficacy, questionnaires were employed in the control and experimental class. Therefore, the research instruments consisted of two instruments which are the reading test and questionnaires. The total items of the reading test include 30 items consisting of 5 items in the form of essay and 25 in the multiple choices. Meanwhile, the statement items of motivation involved 17 items and 30 statement items for self-efficacy.

To attain the data of students' motivation and self-efficacy, the researchers asked students to fill out the questionnaire by ticking off one of the five options of each 
statement provided. The options were always, often, sometimes, rarely, and never. The statement items of motivation covered eager, willingness to succeed, encouragement and need to read, hope and the future ideal, and appreciation and interesting activities to read. Meanwhile, the statement items of self-efficacy involved the level, strength, and generality. The items were no right or wrong answer because the students' responses were in line with their real conditions. The validity and reliability of the instruments were considered.

\subsection{Technique of analyzing data}

This study used descriptive and inferential analysis. The descriptive analysis was aimed at finding out the data of students' reading comprehension, motivation, and self-efficacy attained before and after the treatments in the control and experimental class. The data of those include the mean, median, mode, and standards deviation of scores. Meanwhile, the inferential analysis was the process of making conclusions based on fewer sample data into a more general conclusion. It was dedicated to analyzing the data through statistical analysis, namely normality distribution, homogeneity of variance, and multifactor analysis of variance (ANOVA).

A normality test was conducted by applying One-Sample Kolmogorov-Smirnov formula. The conclusion was made at level 0.05 . Because the significance probability was higher than the significant level 0.05 , the data had a normal distribution. Dealing with the homogeneity test, this study employed Levene test to know the homogeneity of the variance data. The conclusion was drawn at level 0.05 . Because the significance probability was higher than level 0.05 , the variance was homogeneous. To test the research hypotheses, multifactor analysis of variance (ANOVA) 2 × 2 (Two Way ANOVA) was employed. Ha was accepted because Fo was greater than Ft. The conclusion was drawn at level 0.05 . The computation of inferential analysis used IBM SPSS 21.0.

\section{$4 \quad$ Research Findings}

This study aimed to reveal whether the use of ECOLA technique is more effective than that of conventional technique to improve reading comprehension in relation to students' motivation and self-efficacy; whether there is any difference of students' reading comprehension taught by using ECOLA technique viewed from students' motivation and self-efficacy; and whether there is any interaction between ECOLA technique, motivation, and self-efficacy towards students' reading comprehension. This study was conducted from February to May 2019.

The researchers collected data by using the reading test to know students' reading comprehension. The tests were given to the students before and after the treatments. To know students' motivation and self-efficacy, researchers used questionnaires to the two classes, the control and experimental class in the pre-test and posttest. For eight meetings, each group applied different treatments, where the IVA class implemented the ECOLA technique, while the control class was treated by using the conventional 
technique. Then, it was continued by conducting data analysis statistically, the descriptive statistic and the inferential statistic. It was done to test the proposed hypothesis in advance.

Table 2. The result of students' average score in the experimental class

\begin{tabular}{|l|l|c|c|c|c|c|c|}
\hline \multirow{2}{*}{ Variables } & \multirow{2}{*}{ N } & Mean & \multirow{2}{*}{ Std. Deviation } & \multirow{2}{*}{$\begin{array}{c}\text { Std. } \\
\text { Error }\end{array}$} & $\begin{array}{c}\text { 95\% Confidence } \\
\text { Interval for Mean }\end{array}$ \\
\cline { 5 - 8 } & & & & $\begin{array}{c}\text { Lower } \\
\text { Bound }\end{array}$ & $\begin{array}{c}\text { Upper } \\
\text { Bound }\end{array}$ \\
\hline \multirow{2}{*}{ Reading } & Posttest & 29 & 59.83 & 10.640 & 1.976 & 55.78 & 63.87 \\
\cline { 2 - 8 } & Pretest & 29 & 41.03 & 6.161 & 1.144 & 38.69 & 43.38 \\
\hline \multirow{2}{*}{ Motivation } & Posttest & 29 & 62.41 & 8.679 & 1.612 & 59.11 & 65.72 \\
\cline { 2 - 8 } & Pretest & 29 & 48.00 & 5.676 & 1.054 & 45.84 & 50.16 \\
\hline \multirow{2}{*}{$\begin{array}{l}\text { Self- } \\
\text { Efficacy }\end{array}$} & Posttest & 29 & 65.38 & 10.611 & 1.970 & 61.34 & 69.42 \\
\cline { 2 - 8 } & Pretest & 29 & 44.34 & 6.079 & 1.129 & 42.03 & 46.66 \\
\hline
\end{tabular}

Table 3. The result of students' average score in the control class

\begin{tabular}{|l|l|c|c|c|c|c|c|}
\hline \multirow{2}{*}{ Variables } & \multirow{2}{*}{ N } & Mean & \multirow{2}{*}{ Std. Deviation } & \multirow{2}{*}{$\begin{array}{c}\text { Std. } \\
\text { Error }\end{array}$} & \multicolumn{2}{c|}{$\begin{array}{c}\text { 95\% Confidence } \\
\text { Interval for Mean }\end{array}$} \\
\cline { 5 - 8 } & & & & $\begin{array}{c}\text { Lower } \\
\text { Bound }\end{array}$ & $\begin{array}{c}\text { Upper } \\
\text { Bound }\end{array}$ \\
\hline \multirow{2}{*}{ Reading } & Posttest & 29 & 55.21 & 12.462 & 2.314 & 50.47 & 59.95 \\
\cline { 2 - 8 } & Pretest & 29 & 40.72 & 6.284 & 1.167 & 38.33 & 43.11 \\
\hline \multirow{2}{*}{ Motivation } & Posttest & 29 & 58.76 & 9.605 & 1.784 & 55.10 & 62.41 \\
\cline { 2 - 8 } & Pretest & 29 & 46.90 & 6.079 & 1.129 & 44.58 & 49.21 \\
\hline \multirow{2}{*}{$\begin{array}{l}\text { Self- } \\
\text { Efficacy }\end{array}$} & Posttest & 29 & 60.62 & 11.537 & 2.142 & 56.23 & 65.01 \\
\cline { 2 - 8 } & Pretest & 29 & 44.34 & 6.079 & 1.129 & 42.03 & 46.66 \\
\hline
\end{tabular}

Table 4. The summary of two way ANOVA test

\begin{tabular}{|l|c|c|c|c|c|}
\hline \multicolumn{1}{|c|}{ SOURCE } & $\begin{array}{c}\text { Type III Sum of } \\
\text { Squares }\end{array}$ & df & Mean Square & F & Sig. \\
\hline Corrected Model & $5723.079^{\mathrm{a}}$ & 12 & 476.923 & 10.194 & .000 \\
\hline Intercept & 72755.668 & 1 & 72755.668 & $\begin{array}{c}1555.0 \\
48\end{array}$ & .000 \\
\hline Teaching Technique & 8.848 & 1 & 8.848 & .189 & .666 \\
\hline Motivation & 815.903 & 2 & 407.951 & 8.719 & .001 \\
\hline Self-Efficacy & 600.539 & 2 & 300.270 & 6.418 & .004 \\
\hline $\begin{array}{l}\text { Teaching Technique * } \\
\text { Motivation }\end{array}$ & .746 & 1 & .746 & .016 & .900 \\
\hline $\begin{array}{l}\text { Teaching Technique * } \\
\text { Self-Efficacy }\end{array}$ & 236.229 & 1 & 236.229 & 5.049 & .030 \\
\hline Motivation * Self-Efficacy & 38.325 & 2 & 19.163 & .410 & .666 \\
\hline $\begin{array}{l}\text { Teaching Technique * } \\
\text { Motivation * Self-Efficacy }\end{array}$ & 50.918 & 1 & 50.918 & 1.088 & .302 \\
\hline Error & 2105.404 & 45 & 46.787 & & \\
\hline Total & 199706.000 & 58 & & & \\
\hline Corrected Total & 7828.483 & 57 & & & \\
\hline a. R Squared = .731 (Adjusted R Squared =.659) & & & & \\
\hline
\end{tabular}




\section{Discussion}

Based on the result of ANOVA analysis in Table 4, the source of the corrected model column (0.00) was lower than significant level 0.05. It indicated that all the independent variables (the teaching technique, motivation, self-efficacy, and interaction between teaching technique, motivation, and self-efficacy) have a significance effect toward students' reading comprehension at the fifth semester of English language education program. In addition, the source of the intercept column (0.00) was lower than significant level 0.05 . It showed the students' achievement can be increased without the effects of those independent variables. In other words, the reading comprehension can be developed or enhanced without implementing the ECOLA technique and the effects of the motivation, and self-efficacy for the fourth and sixthsemester students of English language education program at higher education.

The mean score of the reading comprehension of students taught by using the ECOLA technique was 59.83, meanwhile, those who were taught by applying brainstorming technique was 55.21. Dealing with the motivation level, students resided at moderate level (58.76) for those taught by brainstorming technique and in high motivation level (62.41) for those taught by the ECOLA technique. Besides, students' selfefficacy was at high level (65.38) by employing the ECOLA technique and in moderate level (60.62) by using the brainstorming technique. Based on the analysis of ANOVA test, the source of the teaching-technique column (0.666) in Table 4 was higher than significant level 0.05 . It indicated that the teaching techniques did not have a significant effect to enhance students' reading comprehension because the two techniques have the same strength to improve students' achievement.

The students' achievement of reading comprehension was affected by students' motivation and self-efficacy level. Table 4 of the motivation column presented that the students' motivation (0.001) was lower than significant level 0.05 . It showed the students' motivation determined the success of the reading comprehension for fifthsemester students of English language education at higher education. Meanwhile, the source of the self-efficacy column (0.004) was lower than significant level 0.05 . It meant that the level of self-efficacy had a significant effect to improve students' reading comprehension.

The finding of this research informed that there is significantly different between teaching reading comprehension by applying the ECOLA technique and teaching reading skills by using the brainstorming technique. The ECOLA technique was more effective than that to enhance students' reading comprehension for the fourth and sixth semester of English language education program at higher education. The indicator of this was the mean score of students who were taught by using ECOLA technique was higher than that of those who were treated by using the brainstorming technique.

By applying ECOLA (Extending Concepts through Language Activities) technique, students can be directed to discuss through language activities to improve their reading skills. This technique also pilots students to conduct a process of monitoring as the results of the interpretation. In addition, the ECOLA technique can encourage learners to discuss effectively to gain a good understanding. The process of 
discussion is carried out to build learners' ability to collaborate in teams. In this technique, the collaboration is a strategic step to improve and gain a better understanding of reading. Therefore, students are able to catch the main idea of the texts they are reading.

In the ECOLA technique, teachers or lecturers can determine and select the reading materials to be read by students in the class. Of course, those reading materials should be appropriate or related to students' existing and background knowledge and also initial experience. In the stage of determining communicative goals, for instance, students are directed to hold a small discussion to discuss the purpose of the reading activities. With the familiar reading materials, students are easier to carry out selfmonitoring about what parts of reading materials they do not understand yet. This learning process makes them enjoy their reading activities and get easy to interpret, compare, and respond to the content of reading texts.

Teaching reading by applying the brainstorming technique is also interesting, but it cannot achieve motion as the ECOLA technique does. The brainstorming technique restricts students to deliver ideas. It is in line with Scarry and Scarry [46] say that this technique helps students deliver students' ideas which come to their mind. It also helps students think about and elaborate main ideas to be delivered and explained to their partners [47]. Moreover, Chesla [48] states "the brainstorming technique allows students to conduct connection with the subject and noting everything that comes to their mind". In short, this technique in teaching reading skills encourages students only to start with the general ideas and finds out the detail information of ideas in the texts. As the result, the students' competency of reading will need longer time to read.

Based on the explanation of the differences between the two techniques (ECOLA and Brainstorming technique) above, it could be summed up that the ECOLA technique has more complex challenging language activities involving all students being communicative and having self-efficacy and motivation in learning participation in the class than the Brainstorming technique does. The ECOLA technique has quite a difference from the brainstorming technique based on reading activities involved in. In short, it could be concluded that the ECOLA technique is more effective than the brainstorming technique to teach reading skills.

Dealing with the students' motivation and self-efficacy, the two aspects seemed to influence students' achievement of reading comprehension. Table 4 presented the source of the motivation (0.001) and self-efficacy (0.004) was lower than significant level 0.05 . It indicated that the level of students' motivation and self-efficacy influenced reading achievement. The mean score of students' motivation in the experimental class and control class was 64.727 and 62.833 respectively. It can be concluded that students having high motivation and self-efficacy have a better reading achievement than those who have moderate and low motivation and self-efficacy for the fourth and sixth semester of English language education program in higher education.

Motivation is considered as a key to the success of reading learning and teaching in general. Sabet, et al [32] state that motivation has a positive effect to support the learning process in the class because students who have high motivation will get better learning achievement. Motivation can support them to have better learning- 
teaching results. The Intrinsic and extrinsic motivations are very important to be achieved by students to learn [49]. In addition, according to Feng and Chen [29] and [50], motivation for students is a critical aspect of learning and getting students to engage in academic activities. Therefore, lecturers should try to convince students that learning is rather than just a grade.

Relating to self-efficacy in teaching reading skills, this part is important to consider because students who have high self-efficacy will be able to solve learning problems themselves. According to Pintrich et al. [42], self-efficacy always refers to the selfappraisal of one's ability which is held to be the basis for self-confidence and motivation to complete and perform students' learning tasks. Chou [37] and [17] found that students having high self-efficacy have better academic performance. In addition, through self-efficacy, lecturers can predict students' critical thinking skills and memory strategies for English reading comprehension.

This study was in line with what Bandura [40] conducted that self-efficacy influences students' emotional responses of fear and anxiety. Students having a high level of self-efficacy tend to become strong students in facing learning difficulties and to exhibit intrinsic motivation. In contrast with those who have less self-efficacy, they feel frustrated in case of failure. Therefore, self-efficacy is referred to learner beliefs about their own academic capabilities and it is important for students to be developed in the reading classroom [18].

In teaching reading comprehension skills using the ECOLA technique, motivation and self-efficacy are needed to support learning activities. It can encourage students to develop reading skills by exploring their capabilities in delivering their ideas which come to their mind in a small group discussion. They are expected to have high motivation and self-efficacy and also are believed that they are able to complete learning reading tasks. Because of these explanations, the ECOLA technique is appropriate to teach reading skills to the students whose motivation and self-efficacy is high.

\section{Conclusion}

The ECOLA technique has some teaching steps

- Determining communicative goals

- Reading silently

- Realizing a comprehension through writing activities

- Discussion

- Write and compare.

This technique can enhance students' reading comprehension skills because it contains a process of monitoring the results of the interpretation. This technique also can encourage students to discuss, write, and compare their ideas to attain a good understanding of texts being read. In the discussion phase, students are directed to have capabilities to collaborate in teams because collaboration is a strategic step to increase and gain a better understanding of reading.

The conclusion of this study can be depicted that: 
- The ECOLA technique was more effective than the brainstorming technique in teaching reading comprehension

- There was the difference of reading achievement of students taught using the ECOLA technique viewed from the motivation and self-efficacy and it was proven by the value of sig. (0.001) and (0.004)

- There was the interaction between ECOLA technique and self-efficacy towards students' reading comprehension but there was no interaction between the technique and motivation.

In addition, there was no significant interaction between the technique, motivation, and self-efficacy because it was indicated by the value of sig (0.302) was higher than significant level 0.05 . To improve students' reading comprehension, the ECOLA technique is recommended and the attention of moderate variables is encouraged.

\section{$7 \quad$ References}

[1] Šamo, R. (2018). EFL reading meta-comprehension from the developmental perspective : A longitudinal case study, Journal of Language and Education, 4(1), 105116.https://doi.org/10.17323/2411-7390-2018-4-1-105-116

[2] Murire, O. T., \& Cilliers, L. (2019). Critical success factors to improve the adoption of social media in teaching and learning: A case study at a traditional university, International Journal of Interactive Mobile Technologies, 13(3), 81-94. https://doi.org/10.3991/ ijim.v13i03.8485

[3] Rojas-osorio, M., \& Alvarez-risco, A. (2019). Intention to use smartphones among Peruvian University students, International Journal of Interactive Mobile Technologies, 13(3), 40-52. https://doi.org/10.3991/ijim.v13i03.9356

[4] Han, M., \& Niu, S. (2019). Effect of computer multimedia assisted word annotation on incidental vocabulary acquisition of English reading, International Journal of Emerging Technologies in Learning, 14(13), 21-32. https://doi.org/10.3991/ijet.v14i13. $\underline{10705}$

[5] Chen, B., \& Wu, J. (n.d.). Promotive effect of psychological intervention on english vocabulary teaching based on hybrid collaborative recommender technology basis for collaborative recommender, International Journal of Emerging Technologies in Learning, 14(15) 14-24. https://doi.org/10.3991/ijet.v14i15.11185

[6] Hendriwanto \& Kurniati, U. (2019). Building reading fluency with mobile assisted extensive, International Journal of Interactive Mobile Technologies,13(3), 84-92. https://doi.org/10.3991/ijim.v13i06.9799

[7] Kamalian, B., Soleimani, H., \& Safari, M. (2017). The effect of task-based reading activities on vocabulary learning and retention of Iranian EFL learners. The Journal of Asia TEFL, 14(1), 32-46. https://doi.org/10.18823/asiatefl.2017.14.1.3.32

[8] Liou, H., \& Li, S. (2014). The effects of computerized graphic organizers on students' performance in English reading and writing tasks, International Journal of Computer-Assisted Language Learning and Teaching, 4(3), 1-19. https://doi.org/10.4018/ ijcallt.2014070101

[9] Guo, L., Zhao, Z., Bai, L., \& Zhao, X. (2017). Design and implementation of English reading examination system based on web platform introduction to relevant computer technol- 
Paper-The Effectiveness of ECOLA Technique to Improve Reading Comprehension in Relation to...

ogies and system. International Journal of Emerging Technologies in Learning, 12(12), 45-56. https://doi.org/10.3991/ijet.v12i12.7959

[10] Yue, N. (2017). Computer multimedia assisted English vocabulary teaching courseware. International Journal of Emerging Technologies in Learning, 12(12), 6778.https://doi.org/10.3991/ijet.v12i12.7955

[11] Mahdizadeh, M., Khoshchehreh, M., \& Hemati, H. (2015). The effect of using Timed reading and Genre-based reading on intermediate EFL language learners' reading comprehension, Modern Journal of Language Teaching Methods, 4(5), 504-511.

[12] Djiwandono, P. (1993). Developing EFL students' reading comprehension strategies, TEFLIN Journal An EFL Journal in Indonesia, 6(1), 48-68.

[13] Sugirin. (2002). How to develop techniques in teaching reading. One-Day Workshop on the teaching of reading_LTC Muhammadiyah University of Yogyakarta, 24 August 2014.

[14] Suhandra, I. R. (2012). The use of reciprocal teaching strategy in teaching reading to improve achievement and self-esteem at the eleventh grade students of multimedia department of SMKN 1 Pujut, Central Lombok. Thesis S2, Applied Linguistics, Yogyakarta State University.

[15] Rachmawati, U. (2016). Developing WebQuests as Reading Instructional Media for the Second Grade Students of SMAN 1 Muntilan in the Academic Year of 2013/2014. S2 Thesis, Applied Linguistic Department, Yogyakarta State University. Retrieved in March 2019 at https://eprints.uny.ac.id/12455/

[16] Feng, R., \& Chen, H. (2009). An analysis on the importance of motivation and strategy in postgraduate's English acquisition. English Language Teaching, 2(3), 9397.https://doi.org/10.5539/elt.v2n3p93

[17] Ahmadian, M. \& Ghasemi, A. A. (2017). Language learning strategies, multiple intelligences, and self-efficacy: Exploring the links. The Journal of Asia TEFL, 14(4), 755772.https://doi.org/10.18823/asiatefl.2017.14.4.11.755

[18] Pajares, F. (2008). Motivational role of self-efficacy beliefs and the writing performance of entering high school students. Psychology in the Schools, 33, 163174.https://doi.org/10.1002/(SICI)1520-6807(199604)33:2<163::AID-PITS10>3.0.CO;2-C

[19] Matsuda, A. (2012). Principles and practice of teaching English as an international language. Canada: Multilingual Matters. https://doi.org/10.21832/9781847697042

[20] Tompkins, G.E. \& Hoskisson (1995). Language arts: content and teaching strategies (3rd Edition). New York: MacMillan Publishing.

[21] Brown, H. D. (2001), Teaching by principles, an interactive approach to language pedagogy, (2nd Ed). New York: Addison Wesley Longman.

[22] Haerazi (2010). Approaches of Language Teaching. Yogyakarta: Samudera Biru.

[23] Zuchdi, D. (2008). Strategy of improving reading skills of comprehension improvement (Strategi Meningkatkan Kemampuan Membaca Peningkatan Komprehensi) Yogyakarta: UNY Press.

[24] Fitriana, M. (2015). Students' reading strategies in comprehending academic reading: A case study in an Indonesian private college, International Journal of Language Education, 2(2) 43-51 https://doi.org/10.26858/ijole.v2i2.6181

[25] Reilly, T. O., Feng, G., Sabatini, J., \& Wang, Z. (2018). How do people read the passages during a reading comprehension test ? The effect of reading purpose on text processing behavior. Educational Assessment, $0(0), \quad 1-19$. https://doi.org/10.1080/10627197. $\underline{2018.1513787}$

[26] Van den Broek, P., Young, M., Tzeng, Y., \& Linderholm, T. (1999). The landscape model of reading. In H. van Oostendorp \& S. R. Goldman (Eds.), the construction of mental representations during reading (pp. 71-98). Mahwah, NJ: Erlbaum. 
Paper-The Effectiveness of ECOLA Technique to Improve Reading Comprehension in Relation to...

[27] Cahyaningati, D. T. \& Lestari, L., A. (2017). The use of multimodal text in enhancing engineering students' reading skill, International Journal of Language Education, 2(2) 65-73 https://doi.org/10.26858/ijole.v2i2.6360

[28] Löwenadler, J. (2019). Patterns of variation in the interplay of language ability and general reading comprehension ability in L2 reading. Language Testing, 36(3), 369390.https://doi.org/10.1177/0265532219826379

[29] Feng, R., \& Chen, H. (2009). An analysis on the importance of motivation and strategy in postgraduates English acquisition. English Language Teaching, 2(3), 9397.https://doi.org/10.5539/elt.v2n3p93

[30] Ellis, R. (1994). The study of second language acquisition. London: Oxford University Press.

[31] Wentzel, K. \& Wigfield, A. (2010). Academic and social motivational influences on stu-

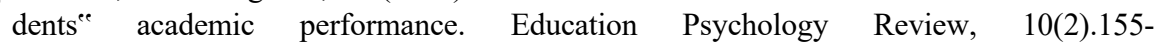
175.https://doi.org/10.1023/A:1022137619834

[32] Sabet, M. K., Tahriri, A., \& Haghi, E. B. (2014). The impact of task-based approach on Iranian EFL learners' motivation in writing research abstracts. Journal of Language Teaching and Research. https://doi.org/10.4304/jltr.5.4.953-962

[33] Kato, F. Yasumoto, S., \& Aacken, S. V. (2007). A Comparative Stud: Motivation of Learners of Japanese, Electronic Journal of Foreign Language Teaching, 4, 41-57. https://e-flt.nus.edu.sg/

[34] Hayes, C., \& Director, I. (2009). Student motivation, blended learning \& an iPOD project in tertiary Japanese language teaching at ANU. Electronic Journal of Foreign Language Teaching, 6, 230-244. https://e-flt.nus.edu.sg/

[35] Conttia, L. M. W. (2007). The influence of learners' motivation on developing autonomous learning in an English for specific purpose course. A dissertation, Applied Linguistics, University of Hong Kong. Retrieved in March 2019.

[36] Chou, M.-H. (2015). Impacts of the Test of English Listening Comprehension on students' English learning expectations in Taiwan. Language, Culture and Curriculum, 28(2), 191208. https://doi.org/10.1080/07908318.2015.1027216

[37] Chou, M.H. (2017). Modeling the relationship among prior English level, self-efficacy, critical thinking, and strategies in reading performance. Journal of Asia TEFL, 14(3), 380397. https://doi.org/10.18823/asiatefl.2017.14.3.1.380

[38] Cohen, A. D. (2010). Focus on the language learner: Styles, strategies and motivation. In N. Schmitt (Ed.), an introduction to applied linguistics (2nd ed.; pp. 161-178). London, UK: Hodder Education.

[39] Wang, S., \& Wu, P. (2008). The role of feedback and self-efficacy on web-based learning: The social cognitive perspective. Computers \& Education, 51(4), 15891598.https://doi.org/10.1016/j.compedu.2008.03.004

[40] Bandura (1997). Self-efficacy: Toward a unifying theory of behavioral change. Psychological Review, 84, 191-215. https://doi.org/10.1037//0033-295X.84.2.191

[41] Pajares, F. (2008). Motivational role of self-efficacy beliefs and the writing performance of entering high school students. Psychology in the Schools, 33, 163-174. https://doi.org/10.1002/(SICI)1520-6807(199604)33:2<163::AID-PITS10>3.0.CO;2-C

[42] Pintrich, P. R., et al. (1991). A manual for the use of the motivated strategy for learning questionnaire (MSLQ). Ann Arbor, MI: National Center for Research to Improve PostSecondary Teaching and Learning. https://doi.org/10.1037/t09161-000

[43] Smith, N. B. (1991). American reading instruction. Newark, DE: International Reading Association. Retrieved in March 2019 from https://www.researchgate.net/publication. 
Paper-The Effectiveness of ECOLA Technique to Improve Reading Comprehension in Relation to...

[44] Tierney et al. (1990). Reading strategies and practices a compendium. USA: Allyn and Bacon.

[45] Kothari, C. R. (2004). Research methodology: method and technique. New Delhi: New Age International Publisher.

[46] Scarry, S. \& Scarry, J. (2008). The writer's workplace with readings: Building college writing skills (6th Ed.). Boston: Thompson Learning, Inc.

[47] Langan (2001). College writing skills with reading (7th Ed.). New York: McGraw-Hill.

[48] Chelsa, E. (2006). Write better essay in just 20 minutes a day (2nd Ed.). New York: Learning Express.

[49] Surastina, S., \& Dedi, F. S. O. (2018). Examining academic writing motivation of prospective Indonesian language teachers using exploratory factor analysis. International Journal of Instruction, 11(2), 15-24. https://doi.org/10.12973/iji.2018.1122a

[50] Tiwery, D. S. \& Souisa, T.R. (2019). Inside-outside circle as the way in building students' motivation and interaction in speaking classroom activities. International Journal of Language Education, 3(1), 34-45 https://doi.org/10.26858/ijole.v1i1.6703

\section{Authors}

Haerazi is an English lecturer at Postgraduate of English Language education, Mandalika University of Education, Indonesia, since 2010. His research interests are focused on TEFL and intercultural language learning, language and cultures, teaching of the four language skills, and Mobile-assisted language learning (MALL). He has published a number of articles related to teaching English as a Foreign Language and Teaching media. ORCID: 0000-0003-3933-4131.Email: haerazi@ikipmataram.ac.id

Lalu Ari Irawan is an English lecturer at English Language Education, Graduate School, IKIP Mataram, since 2007. His research interests are dedicated on English language teaching, cultural studies, Language testing, and ELT curriculum and materials development. He has distributed his some articles dealing with TEFL methodologies as a part of English for a specific purpose (ESP) course design. ORCID: 00000002-3833-5581.h

Article submitted 2019-08-11. Resubmitted 2019-10-01. Final acceptance 2019-10-21. Final version published as submitted by the authors. 